DOI: $10.2478 /$ ace-2013-0010

\title{
INVESTIGATING THE EFFECT OF THE NUMBER OF END-PANEL STUDS ON THE SEISMIC PROPERTIES OF COLD-FORMED LIGHT-STEEL SHEAR-PANEL BRACES
}

\author{
MOHAMMAD REZA JAVAHERI TAFTI ${ }^{1}$, FARHAD BEHNAMFAR $^{2}$
}

\begin{abstract}
Detailed investigation of the effect of the number of end-panel studs on the seismic properties of light-steel shear-panel braces in cold-formed steel frames and in particular the associated response modification coefficients (R) factor, are presented in this paper. A total of 6 full-scale $1200 \times 2400$ $\mathrm{mm}$ specimens are considered, and the responses investigated under a standard cyclic loading regime. Of particular interest are the specimens' maximum lateral load capacity and deformation behavior as well as a rational estimation of the seismic response modification factor. The study also looks at the failure modes of the system and investigates the main factors contributing to the ductile response of the tested shear-panel braces in order to suggest improvements so that braces respond plastically with a significant drift and without any risk of brittle failure, such as connection failure or stud buckling.
\end{abstract}

Key words: Cold-Formed Steel, Light Steel Frames, Shear-panel bracing, Lateral Performance, Response Modification Factor

\section{INTRODUCTION}

The use of cold-formed steel (CFS) members as the main framing elements in a structure is becoming more accepted in the housing industry, especially in low rise residential buildings, due to its unique advantages such as being cost-effective, light-weight and very easy to work with. On the other hand, one of the disadvantages of these systems is the limited number of stories in high seismic regions like Iran mostly due to the low lateral resistance of the system and the inadequacy of data available on the lateral response of these systems. The common lateral load resisting system for these buildings is X-strap bracing which exerts high demand on connections. Alternatives such as steel shear plates (shear-panel braces) that are screwed to the face of the walls can potentially increase the lateral load resistance capacities. Careful detailing of the braced panel, including the number of end-panel studs and the spacing of the connecting screws can

1 Instructor, Islamic Azad University, Isfahan science and research branch, Isfahan, Iran, Javaheri@, taftiau.ac.ir

2 Assistant Professor, Islamic Azad University, Isfahan science and research branch, Isfahan, Iran, farhad@cc.iut.ac.ir 
bring about the much needed higher capacities for shear-panel braces. A rational estimation of the response modification factor, $\mathrm{R}$, as well as the achievable ductility and strength is needed to allow more effective use of steel shear-panel bracing.

This study investigates the effect of the number of end-panel studs on the lateral load capacities of steel shear-panel braces and the corresponding response modification factor. The experimental procedure is explained later following a review of available guidelines and past studies.

\section{Available design guidelines}

\subsection{AISI STANDARDS AND ASCE}

AISI has published several standards, including: Standard for Cold-Formed Steel Framing - Prescriptive Method for One and Two Family Dwellings [1]; North American Specification for the Design of Cold-Formed Steel Structural Members [2]; and a series of standards for cold-formed steel framing - General Provisions [3], Header Design [4], Lateral Design [5], Wall Stud Design [6] and Truss Design [7]. Although the design and construction of cold-formed steel structures shall comply with the North American Specification [2] and the General Provisions [3], seismic design regulations have been stipulated in the Lateral Design [6] along with some design guidelines for various special shear wall types and strap bracing [8-10]. The Lateral Design Standard does not enforce any special rule other than specifications and general provisions for shear walls when the response modification factor is considered as being smaller than 3. However, for a response modification factor greater than 3 , some additional requirements shall apply, mainly described for diagonal strap bracing members and anchorage of braced wall segments to resist uplift as well as perimeter members at opening. The alternative between $\mathrm{R} \leq 3$, with no special requirements, or taking the advantages of $\mathrm{R}>3$, in addition to some essential detailing, is permitted only for the seismic design categories A to $\mathrm{C}$. In the seismic design categories $\mathrm{D}$ to $\mathrm{F}$, using an $\mathrm{R}$ equal to or less than 3 is not permitted, and the designer must use the special seismic requirements with $\mathrm{R}$ greater than 3 to ensure that the system behaves properly in high seismic regions. Eventually, the code introduces seismic response modification factors for different basic seismic force-resisting systems; however, it does not cover all available lateral bracing systems which are currently used in the CFS residential industry.

ASCE7 [11] stipulates that the design of light-weight cold-formed steel structures to resist seismic loads shall be in accordance with the requirements of AISI. However, it requires that for those systems, e.g. a K-braced system, which are not detailed in accordance with AISI, one shall use the R factor designated for "Structural steel systems not specifically detailed for seismic resistance" which is equal to 3 . 


\subsection{NEHRP PROVISIONS, FEMA 450 AND P750}

American NEHRP recommended seismic provisions FEMA 450 [12] and FEMA P750 [13] specify that the design of cold-formed carbon or low-alloy steel members to resist seismic loads shall be in accordance with the requirements of AISI Specifications and AISI General Provisions. However, the allowable stress and load levels in AISI are incompatible with the force levels calculated in accordance with FEMA provisions. Therefore, it is essential to adjust the provisions of AISI for use with the FEMA provisions. It is mentionable that these modifications affect only designs involving seismic loads.

Although the code provides the seismic response modification factors for some CFS framing systems, it does not cover all of the many different systems currently used in practice. As a consequence, for systems not mentioned in the code, the designer has to use the R factor corresponding to "Steel Systems Not Specifically Detailed for Seismic Resistance", which is 3 .

\subsection{TI 809-07}

The Technical Instructions, TI 809-07 [14], were originally developed for the design and construction of cold-formed steel military constructions and are used extensively by the U.S. Army Corps of Engineers, USACE. The code is primarily based on FEMA 302 [15] though with some modifications in the design load considering over-strength of straps. Although the code provides some general recommendations for seismic design of cold-formed steel shear walls, it mainly focuses on diagonal strap configurations. So, a seismic response modification factor is suggested only for CFS shear panels with diagonal strapping, which is 4 . The code mentions that the $\mathrm{R}$ factor in the direction under consideration at any story shall not exceed the lowest value for the seismic force resisting system in the same direction considered above that storey, excluding penthouses. Other structural systems, i.e. dual systems, may be used in combination with these CFS panels, but then the smallest $\mathrm{R}$ value for all systems in the direction under consideration must be used for determining the loads applied to the entire structure in that direction. A different structural system may be used in the orthogonal direction with different $\mathrm{R}$ values, and the lowest $\mathrm{R}$ value of that direction shall be used in determining loads in the orthogonal direction.

\subsection{UBC 97 AND IBC 2000}

UBC 97 [16] and IBC [17] highlight that the design, installation and construction of CFS structural and non-structural framing shall be in accordance with AISI. Also, the $\mathrm{R}$ factor shall be based on ASCE 7 for the appropriate steel systems which are designed and detailed in accordance with the provisions of AISC. Although UBC allows a maximum height of five stories for steel stud wall systems in seismic zones, provided that 
they comply with some specifications, IBC limits the use of CFS systems only to two stories considering AISI provisions.

\subsection{AS/NZS 4600}

Although the earthquake loading standard of Australia, AS1170.4 [18], does not cover cold-formed steel structures, the Australian cold-formed steel structures standard, AS/NZS 4600-05 [19], requires that when cold-formed steel members are used as the primary earthquake resisting element, the selected response modification factor shall not be greater than 2, unless specified otherwise. However, as Australia is located in a low seismic zone, wind loads often dominate the design of low-rise cold-formed steel buildings and therefore such a low value for $\mathrm{R}$ factor does not affect designs. Little research attention has been paid to the evaluation of $\mathrm{R}$ factors in Australia for the same reason.

A simple but important conclusion from the above review is that there is not a universal agreement on the value of response modification factor, $\mathrm{R}$, and more studies are required to clarify this matter.

\section{Past StUdies}

Serrette [20] conducted both static and cyclic load tests on walls with $3-1 / 2 \times 1-5 / 8$ studs spaced at $24 \mathrm{in}$. Double studs (back-to-back) were used at the ends of the walls. Tests included panels with many different types of bracing including steel sheet sheathing. The sheathing or bracing was placed on only one side of the panels. The tests were planned to answer remaining questions on OSB and plywood sheathed walls, to obtain design data for panels with high aspect ratios, and to obtain design data for walls with steel X-bracing or steel sheathing. Failure of steel sheathed panels resulted from rupture of the steel sheet along the line of screws at the edges. Diagonal "tension field" patterns were not observed. Decreasing the fastener spacing and increasing the steel sheathing thickness was effective in increasing the maximum load. The maximum loads for panels with an aspect ratio of 4:1 were similar (within 10 percent) to those for OSB panels with the same aspect ratio and fastener spacing. Displacement at maximum load was 2 in. or more for panels with an aspect ratio of 4:1, and averaged $1.30 \mathrm{in}$. for the panel with a ratio of $2: 1$.

Kawai et al. [21] conducted a series of full-scale experimental tests on different CFS lateral bracing systems which again included steel sheets. Of particular interest was the in-plane shear resistance of the specimens as well as their ductilities. They concluded that while the strap-braced frame was very ductile with remarkable pinching behaviour, the walls with thin steel sheets, plywood and gypsum board showed less ductility and moderate pinching. They also claimed that the behaviour of walls with a combination of two different lateral bracing systems was reasonably close to the behaviour of the two superimposed. 
Berman et al. [22] investigated CFS frames using both X-braced and steel-plated shear walls. The main aim of their research was to provide an engineering guideline for evaluating both of these types of CFS walls considering stiffness, ductility and energy dissipation. They presented and compared the results of six full-scale $3660 \times 1830 \mathrm{~mm}$ CFS frames including four concentrically braced frames, and two steel plate shear walls. They used the ATC-24 [23] testing protocol to perform a quasi-static testing method. During the tests, the specimen's top horizontal displacement was considered as the drift control parameter. They reported that the maximum initial stiffness was related to the X-braced frame specimen while the maximum ductility was provided by steel plate shear wall. Interestingly, using scaled hysteretic results, they found that the energy dissipated was similar for both X-braced frames and steel plate shear walls.

Schafer and Hiriyur [24] argued against available models of the strength of sheathed wall systems and presented some new ideas for improvements. They indicated that the strength of sheathed wall systems is significantly larger than the similar unsheathed walls. They reported that there is a strength increase of $70 \%$ on both-side sheathed stud walls with dry gypsum board, compared to the unsheathed stud frames. They believed that the available AISI Specification for sheathed wall stud systems is difficult, and is implemented only for double-sided sheathing. They presented an analytical discussion, which led to several conclusions about the sheathed wall systems' performances and indicated that the stiffness of the diaphragm is not uniform and is not solely derived from stud spacing, as assumed in AISI. They also provided numerical tools to assess the elastic buckling capacity of both single-side and double-side sheathed studs.

Fulop and Dubina [25] performed six series of full scale wall tests with various types of cladding arrangements including X-strap braced frames, corrugated sheathed walls, gypsum board sheathed panels, and oriented strand board (OSB) sheathed panels. Each serries consisted of identical wall panels tested using both monotonic and cyclic loading regime. They found that in most specimens, strengthening of the walls' corners is fundamental as the failure starts at the bottom track in the anchor bolt region. Thus, the corner detail should be designed so that the uplift force is directly transmitted from the brace or corner stud to the anchoring bolt, so that it does not induce bending in the bottom track. Also they reported that the seam fastener represented the most sensitive part of the corrugated sheet specimens; damage is gradually increased in seam fasteners, until their failure causes the overall failure of the panel.

As is seen, the amount of information available with regard to the capacities of steel sheathed walls is not adequate. A much wider range and investigation of parameters affecting the capacity is needed. 


\section{SEISMIC RESPONSE MODIFICATION FACTOR}

The response modification factor is commonly expressed in terms of its two main components: ductility reduction factor $\left(\mathrm{R}_{\mathrm{d}}\right)$ and structural over-strength factor $\left(\Omega_{0}\right)[26,27]$. The $\mathrm{R}$ factor is defined as:

$$
R=R_{d} \times \Omega_{0}
$$

The components of the response modification factor are defined using Figure 1, which indicate the actual and the elastic performance of a structural system as well as the idealized bilinear force-displacement curve, as:

$$
R_{d}=\frac{V_{e}}{V_{y}}, \quad \Omega_{0}=\frac{V_{y}}{V_{s}}
$$

and the $\mathrm{R}$ factor can then be regenerated as:

$$
R=R_{d} \times \Omega_{0}=\frac{V_{e}}{V_{y}} \times \frac{V_{y}}{V_{s}}=\frac{V_{e}}{V_{s}}
$$

where $V_{e}, V_{y}$ and $V_{s}$ correspond to the structure's elastic response strength, the idealized yield strength and the first "significant yield" strength respectively.

The evaluation of $\mathrm{R}$ factor and its components is a controversial structural concept which has been discussed for many years; however, some defined approaches are more popular than others. In fact, the way that different parameters and an idealized bilinear curve would be addressed has significant effects on the estimated R factors. In this research study, the proposed method by FEMA $[12,26,28]$ is used to evaluate the response modification factor for light steel shear wall systems.

Figure 1 illustrates the general structural response and the method which has been used to idealize a force-displacement curve based on FEMA 356 [28]. In this study, based on the references [29], [30], [31], [32], and [33], it is assumed that the target displacement is the maximum structure's drift prior to a considerable fall in the structure's strength. The code stipulates that the effective yield strength shall not be taken to be greater than the maximum base shear force at any point along the actual curve.

\subsection{Ductility Reduction Factor, $\mathrm{R}_{\mathrm{D}}$}

$R_{d}$ has received considerable attention amongst researchers and depends on the structural properties such as ductility, damping and fundamental period of vibration, as well as characteristics of the earthquake ground motion. Newmark and Hall [34] developed the set of equations (5) to (7) defining $R_{d}$ in terms of a structure's ductility, which is 


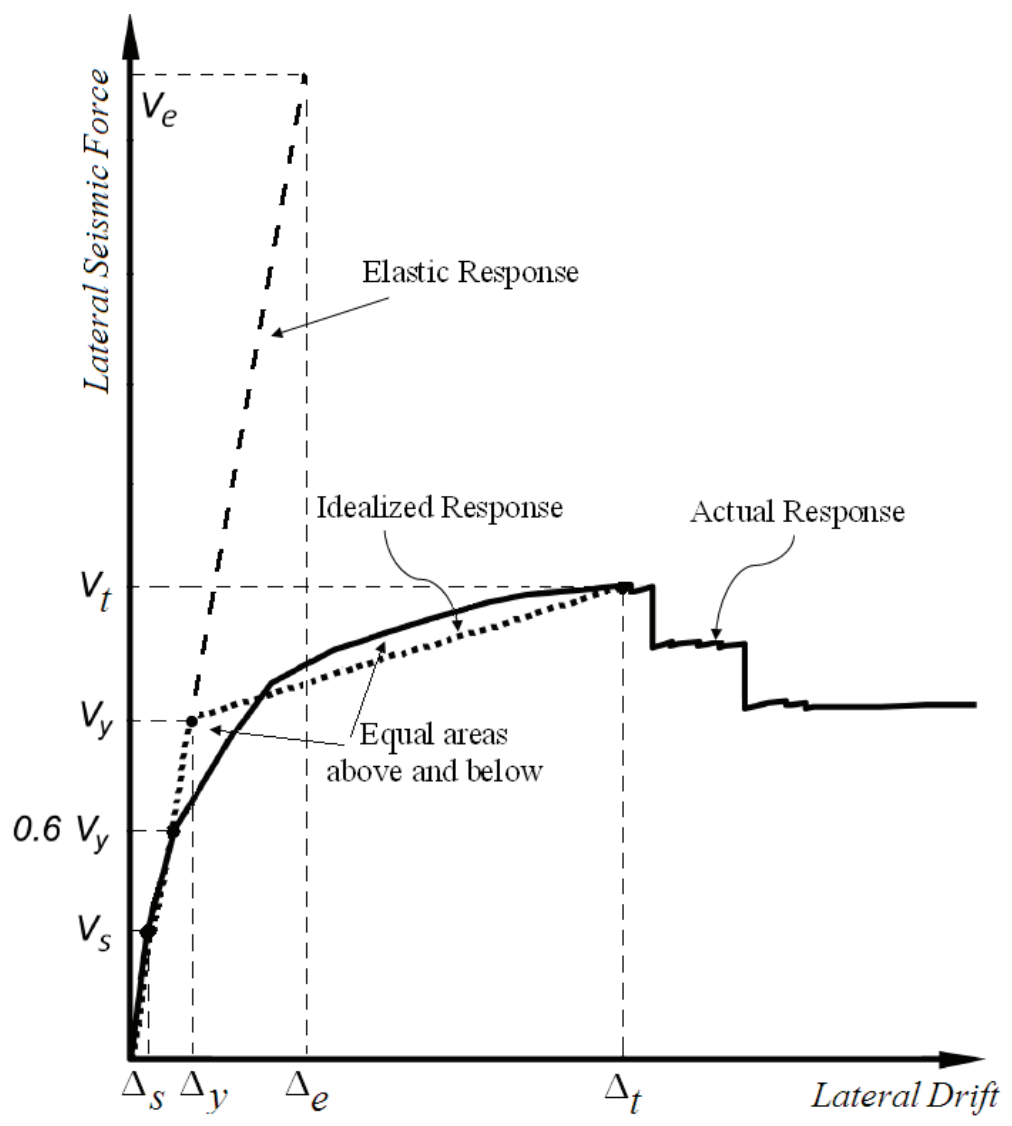

Figure 1. General structural response, illustrating FEMA's concepts

expressed in terms of maximum structural drift, $\Delta_{\max }$, and the drift corresponding to the idealized yielding point, $\Delta_{y}$, as:

(4) Ductility: $\quad \mu=\frac{\Delta_{\max }}{\Delta_{y}}$

(5) Newmark and Hall: $\left\{\begin{array}{r}R_{d}=\mu \mathrm{T}>0.5 \mathrm{sec} \\ R_{d}=\sqrt{2 \mu-1} 0.1<T<0.5 \mathrm{sec} \\ R_{d}=1 \quad \mathrm{~T}<0.03 \mathrm{sec}\end{array}\right.$ 


\subsection{Over-Strength Factor, $\Omega_{0}$}

The over-strength factor is intended to address possible sources that may contribute to strength beyond its nominal value. FEMA 450 [26] categorized these characters to three main components including: the design over-strength, $\Omega_{D}$, the material over-strength, $\Omega_{M}$, and the system over-strength, $\Omega_{S}$; and suggested a typical range for each.

\section{OBJeCtives AND SCOPE OF RESEARCH}

As mentioned before, a better understanding of the behavior of light steel shear panels is required in order to allow more effective designs and potential higher capacities. The behavior of these systems is not completely understood as yet, because most previous studies have been conducted on the strap-bracing system as can be seen in the literature and codes. The aim of the current research is to evaluate the seismic performance of different configurations of light steel shear walls systems. Also, the effect of the number of end-panel studs on their seismic properties is evaluated. This evaluation is completed by estimation of the seismic response modification factor followed by a comparison with the recommended code values for the $\mathrm{R}$ factor.

It is necessary to mention that the walls which are studied here are unlined, and the positive effect of gypsum board on the lateral performance of the frame under cyclic loading is ignored. This is due to the fact that post-earthquake observations of timber frame structures in the Northridge earthquake have shown that many gypsum board shear walls failed under imposed dynamic load [35]. Also, some design codes [36] have recommended neglecting the gypsum board's contribution and relying only on the bare steel frames.

\section{Test SETup}

\subsection{TESTING RIG AND InSTRUMENTATION}

The general configuration of the testing rig is shown in Figure 2. Each specimen was installed on the rig between the fixed support beam at the top and a rigid loading beam at the bottom. A strong combination of washers and nuts was used to ensure that there was no possibility of slip between the tracks and the beams. An accurate Horizontal Drift (HD) transducer was used to evaluate the horizontal displacement of the top track. Also, one load-cell was used to measure the racking resistance. All data from the transducers and load-cell were analyzed and transferred to the computer using Lab View Signal Express software [37]. The load-displacement curve of each frame was then plotted. 


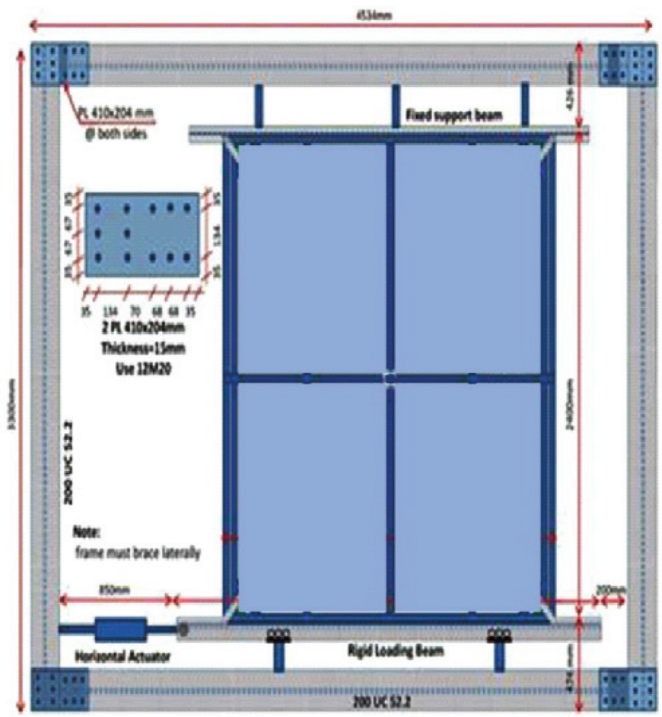

Figure 2. Testing rig diagram and notation convention

\subsection{LOADING PROTOCOL}

The cyclic loading regime that has been used in this study is based on Method B of ASTM Standard [38], which was originally developed for ISO (International Organization for Standardization) standard 16670, at the maximum lateral amplitude of $75 \mathrm{~mm}$.

Method B is used in this study with the lateral amplitude independent of monotonic testing. Moreover, although $75 \mathrm{~mm}$, or $3.125 \%$, inter-storey drift ratio was the maximum amplitude of the actuator, it was considered adequate, since the maximum allowable storey drift ratio specified by the Standard FEMA450 is 2.5\% [12]. The average loading velocity was about $2 \mathrm{~mm} / \mathrm{s}$ which is compatible with the ASTM E2126-07 recommendation that the loading velocity must be in the range of $1-63 \mathrm{~mm} / \mathrm{s}$.

\section{EXPERIMENTAL PROGRAM}

The program consisted of testing six $1200 \times 2400 \mathrm{~mm}$ full-scale frames. To investigate the hysteretic lateral performance of steel shear panels and the effects of the number of end-panel studs in these systems, two types of specimens were tested as shown in Figure 3. In specimens type I, one end stud and in type II, two studs were placed. Three walls of the same type were constructed for each type.

The shear panels were tested in the Seismic Research Laboratory of the Taft Azad University using a specially made testing rig illustrated previously. All of the frame 
elements, such as top and bottom tracks, noggins and studs were made by an identical C-section of dimensions $90 \times 36 \times 0.75 \mathrm{~mm}$. The section structural material properties are shown in Table 1; and the detailed section geometry is shown in Figure 4.

In all specimens, a galvanized steel plate with the mechanical properties shown in Table 2 on one side of the wall was screwed to the panel. All components of the panel (but the steel plate) were connected together at each flange using just one rivet with the shear strength capacity and tensile strength capacity of $3.3 \mathrm{KN}$ and $3.8 \mathrm{KN}$ respectively.
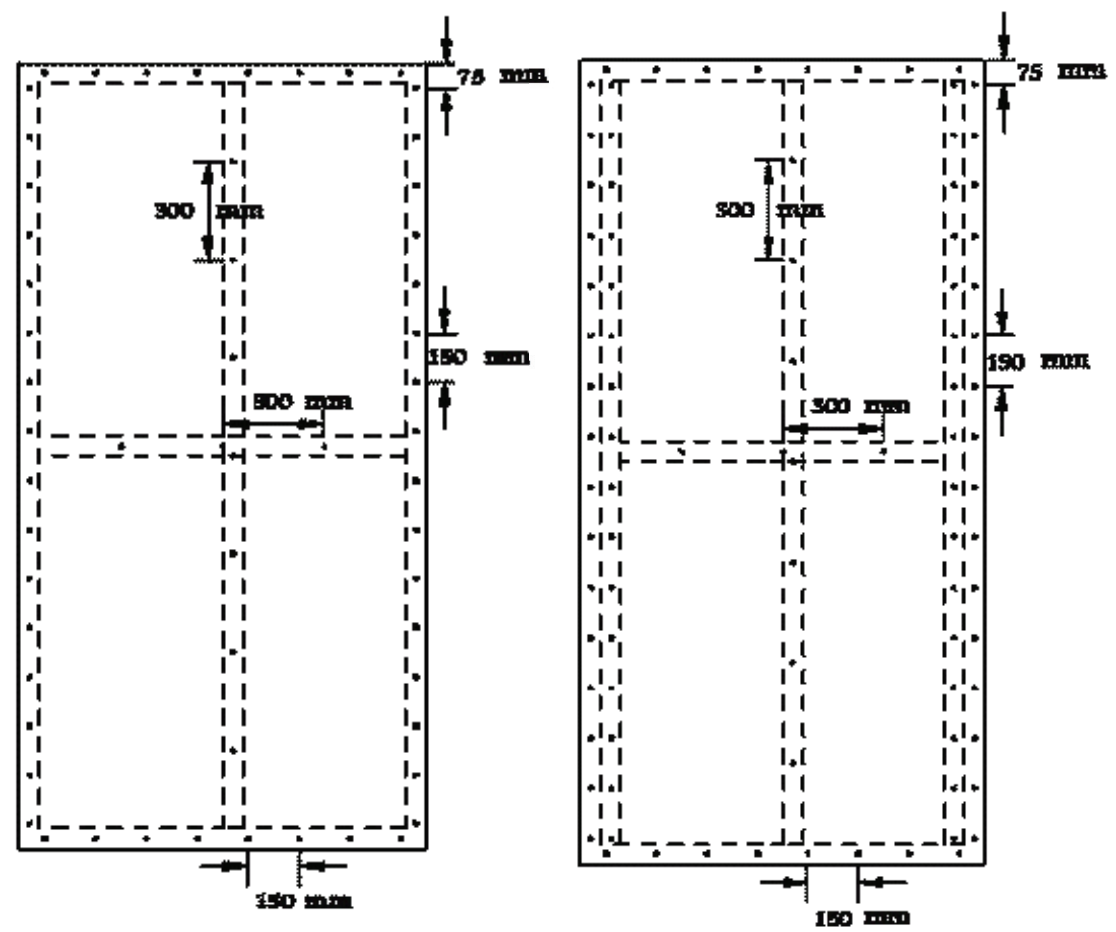

Figure 3. General configuration of specimens Types I and II

Table 1

Mechanical properties of the C-section stud

\begin{tabular}{|c|c|c|c|}
\hline Nominal Grade & $550 \mathrm{MPa}$ & Yield Strain & $0.45 \%$ \\
\hline Nominal Thickness & $0.55 \mathrm{~mm}$ & Ultimate Stress, Fu & $617 \mathrm{MPa}$ \\
\hline Elastic Modulus & $169 \mathrm{GPa}$ & Ultimate Strain & $2.86 \%$ \\
\hline Yield Stress, Fy & $592 \mathrm{MPa}$ & $\mathrm{Fu} / \mathrm{Fy}$ & 1.04 \\
\hline
\end{tabular}




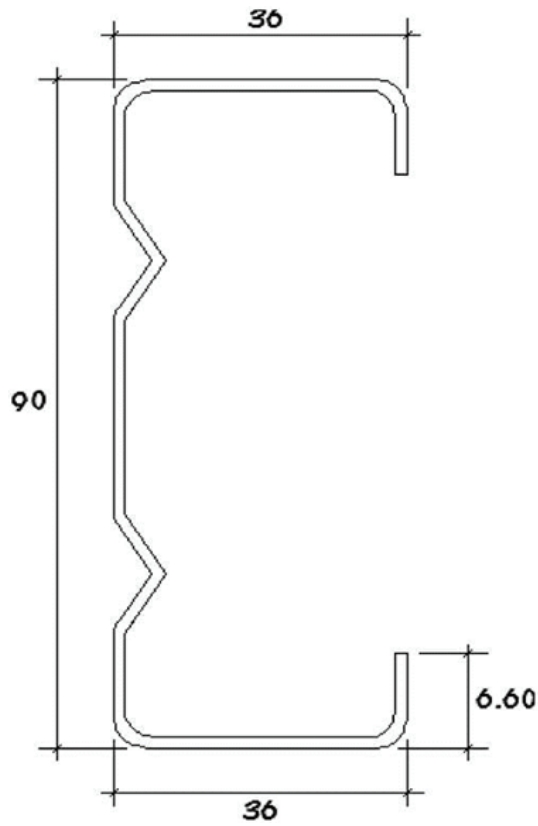

Figure 4. Detailed dimension of stud C $90 \times 36 \times 0.75 \mathrm{in} \mathrm{mm}$

Table 2

Mechanical properties of galvanized plate

\begin{tabular}{|c|c|c|c|}
\hline Nominal Thickness & $0.60 \mathrm{~mm}$ & Yield Strain & $0.155 \%$ \\
\hline Elastic Modulus & $200 \mathrm{GPa}$ & Ultimate Stress, Fu & $348 \mathrm{MPa}$ \\
\hline Yield Stress, Fy & $290 \mathrm{MPa}$ & Fu/Fy & 1.2 \\
\hline
\end{tabular}

\section{EXPERIMENTAL RESULTS}

\subsection{SPECIMENS type I}

The first phenomenon which was observed during the test was elastic buckling in the steel sheathed plate followed by rivet tilting and hole bearing at the top and the bottom tracks. These specimens lost their resistance as a result of screw pull-out of the holddown at the middle and side chords following stud buckling.

Failure modes for this type of specimens are shown in Figure 5, and one of the hysteretic curves is shown in Figure 6. The combined hysteretic envelope curve of all 3 specimens of this type is shown in Figure 7. 

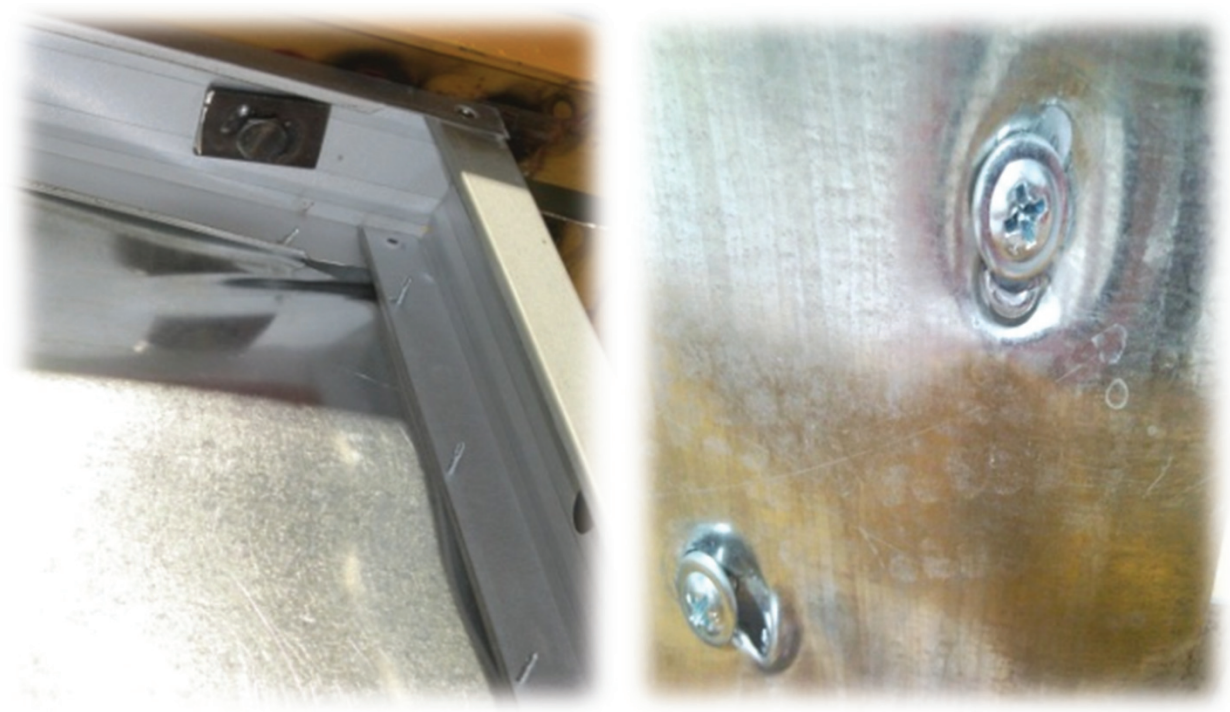

a
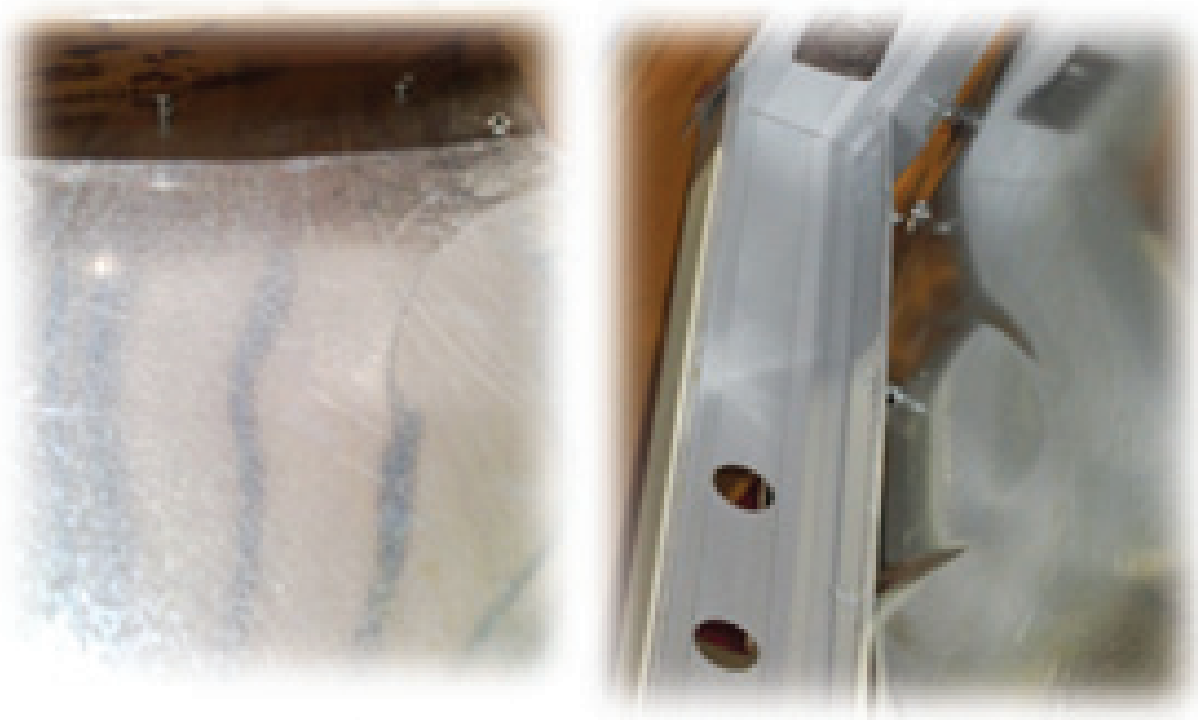

b

Figure 5. Failure modes of specimens type I

a. Rivet tilting and hole bearing; b. Screw pull-out 


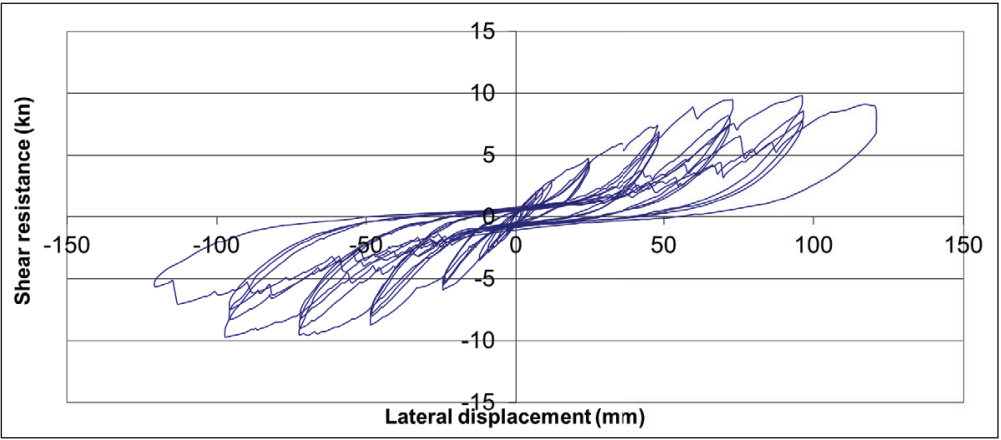

Figure 6. Hysteretic curve

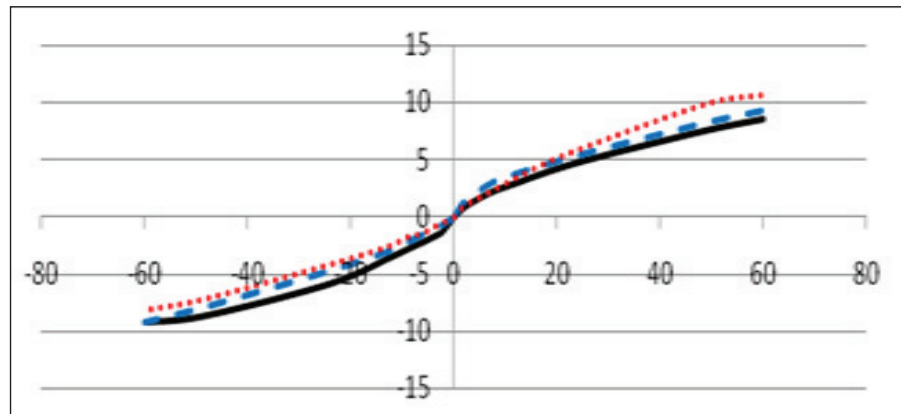

Figure 7. Hysteretic envelope curve for specimens type I

\subsection{SPECIMENS TYPe II}

In this type of specimens, end-panel members were made of double studs. The hysteretic envelope curve for specimens type 2 is shown in Figure 8. Although some elastic buckling in the steel plate braces as well as some local and distortional buckling at the

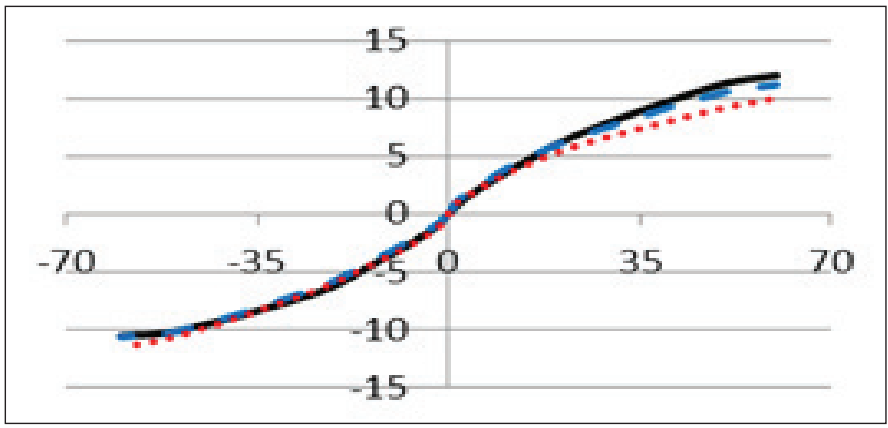

Figure 8. Hysteretic envelope curve for specimens type II 

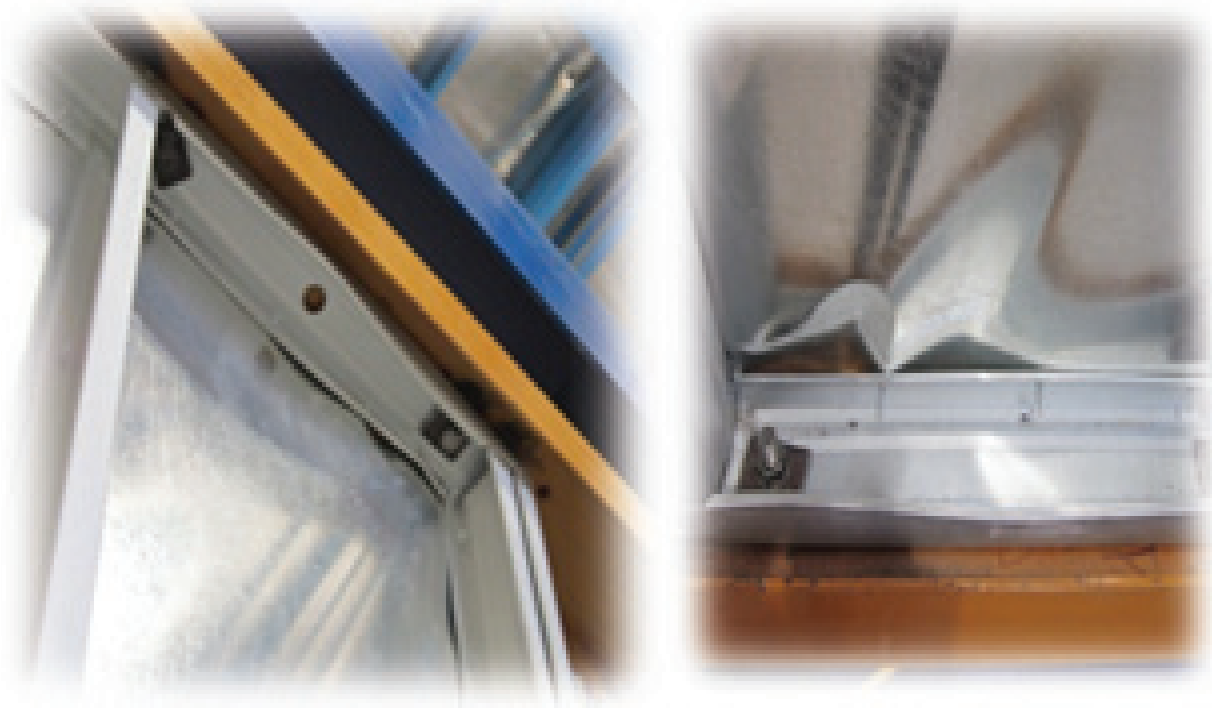

a
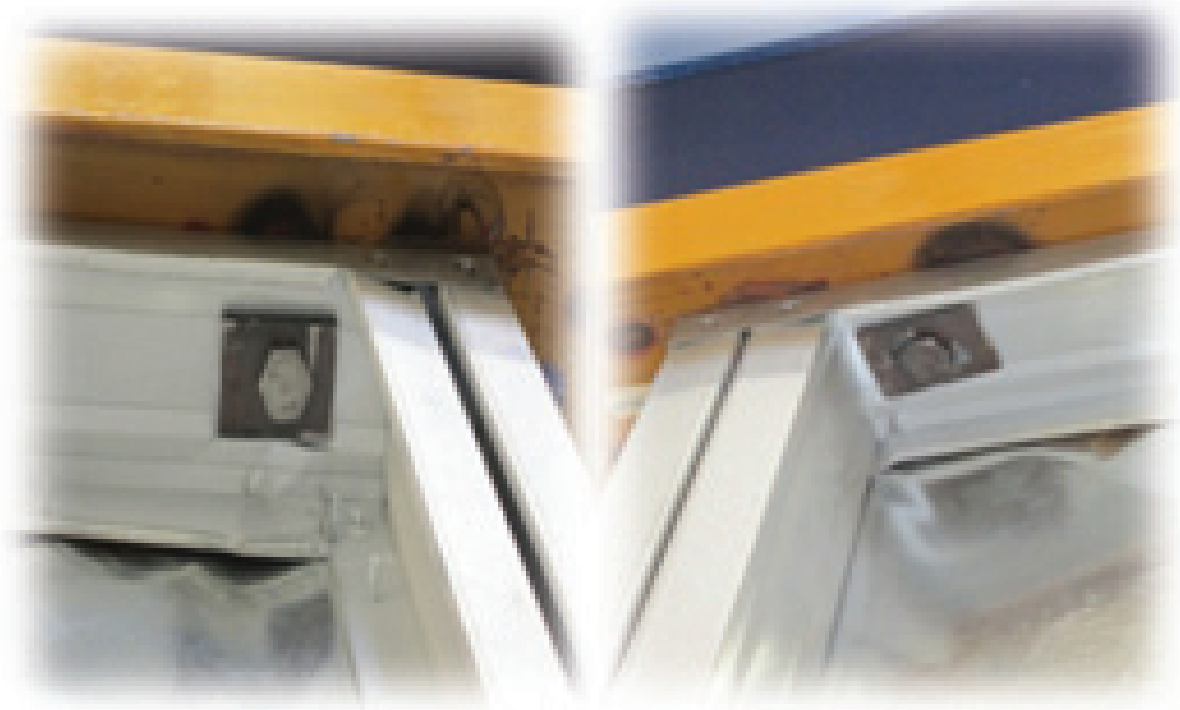

b

Figure 9. Failure modes of specimens type II a. Top and bottom local buckling; $b$. tearing of the bottom track's flange $b$ 
top track flanges were observed during the test, the main fall of the panel's resistance occurred in the first cycle of $+96 \mathrm{~mm}$ lateral displacement which was again because of the screws pull-out mainly in the bottom hold-down devices followed by stud buckling as shown in Figure 9.

It is important to mention that the effects of vertical loading are neglected in these tests because it is assumed that the frames are designed only for lateral loads, and at the time of design the vertical and the lateral loads are separately allowed for.

\section{Evaluation OF R FACTOR}

The specimens' hysteretic envelope curves are used to determine the response modification factors following these steps: Firstly, the idealized bilinear curve is evaluated using the method presented in FEMA 356 [28]. Secondly, the ductility reduction factor, $\mathrm{R}_{\mathrm{d}}$, is evaluated via the first part of Equation 2. The equation requires both $V_{e}$ and $V_{y}$ which can be estimated based on Figure 1. $V_{e}$ is calculated based on the concept of equal energy and $V_{y}$ is evaluated using the idealized bilinear curve which is explained in detail in Section 4 of this paper. For the calculation of $R_{d}$ based on Newmark's method, the ductility factor, $\mu$, is calculated using Equation 4, which requires the idealized bilinear curve to be drawn first in order to determine $\Delta_{\max }$ and $\Delta_{y}$. Here Equation 6 can be used, as the fundamental period of CFS structures is usually assessed between 0.1 and 0.5 sec [39]. The third step is to establish over-strength factor, $\Omega_{0}$, using the second part of Equation 2, employing $V_{y}$ and $V_{S}$.

Table 3

The evaluated response modification factors based on FEMA provisions

\begin{tabular}{|c|c|c|c|c|c|}
\hline \multirow{2}{*}{ Type } & Specimens & $\mathrm{R}$ & $\begin{array}{c}\text { Ultimate Capacity } \\
(\mathrm{kn})\end{array}$ & Ave. R & $\begin{array}{c}\text { Ave. Ultimate } \\
\text { Capacity }\end{array}$ \\
\hline \multirow{3}{*}{ I } & T-I-1 & 6.9 & 8.5 & \multirow{2}{*}{6.3} & \multirow{2}{*}{9.4} \\
\cline { 2 - 4 } & T-I-2 & 5.1 & 9.3 & & \\
\cline { 2 - 5 } & T-I-3 & 6.9 & 10.6 & \multirow{2}{*}{6.6} & \multirow{2}{*}{11.4} \\
\cline { 2 - 5 } II & T-II-1 & 6.6 & 12 & \\
\cline { 2 - 5 } & T-II-2 & 6.8 & 11.2 & \\
\hline
\end{tabular}

\section{CONCLUSIONS AND RECOMMENDATIONS}

Comparing the results to other experiments performed by the authors and other researchers, it can be said that both specimen types have relatively high maximum drifts, $\Delta_{\max }$, and strengths in comparison with strap bracing systems. Hence, the use of a light 
steel shear wall system is possible in high seismic regions where the earthquake loads, and thus the required lateral resistance capacity, are high.

According to the current research results the following conclusions can be made:

1. Having a larger enclosed area in the hysteretic curves represents a more favorable lateral resisting response for these frames as the frame with a larger enclosed curve represent a higher R-factor

2. Failure modes that observed during the tests was elastic buckling and tearing of the plate in the vicinity of connections, hole bearing and rivet tilting, Screw pull-out, local buckling of track's flange and plastic buckling of jamb studs.

3. In specimens type I (one end-panel stud), both track and stud failure was observed while in specimens type II (two end-panel studs), no failure in the chord members was observed.

4. The average $\mathrm{R}$ factor in specimens type I was 6.3 and in specimens type II was 6.6 which is a difference of only about $5 \%$. This difference is not large suggesting that the number of end-panel studs does not affect the R-factor considerably.

5. The average ultimate capacity for specimens type I was $9.4 \mathrm{kN}$ and for specimens type II, $11.4 \mathrm{kN}$. This is a considerable difference suggesting that the use of double studs is favourable.

\section{REFERENCES}

1. AISI, Standard for cold-formed steel framing - prescriptive method for one and two family dwellings 2001, American Iron and Steel Institute: Washington, D.C.

2. AISI, North American specification for the sesign of cold-formed steel structural members. 2001, American Iron and Steel Institute: Washington, D.C.

3. AISI, Standard for cold-formed steel framing - General provisions. 2004, American Iron and Steel Institute: Washington, D.C.

4. AISI, Standard for cold-formed steel framing-Header design. 2004, American Iron and Steel Institute: Washington, D.C.

5. AISI, Standard for cold-formed steel framing - Lateral design. 2004, American Iron and Steel Institute: Washington, D.C.

6. AISI, Standard for cold-formed steel framing - Wall stud design. 2004, American Iron and Steel Institute: Washington, D.C.

7. AISI, Standard for cold-formed steel framing - Truss design. 2004, American Iron and Steel Institute: Washington, D.C.

8. AISI, Design of cold-formed steel shear walls. 1998, Steel Framing Alliance.

9. AISI, Performance of cold-formed steel-framed shear walls: Alternative configurations Research report RP 02-7. 2002, REVISION 2006, Steel Framing Alliance: Washington, D.C.

10. AISI, Code of standard practice for cold-formed steel structural framing, Practice guide CF06-1. 2006, American Iron and Steel Institute: Washington, D.C.

11. ASCE7-05, ASCE 7-05 Minimum design loads for buildings and other structures. 2005, ASCE: USA.

12. FEMA-450, NEHRP recommended provisions for seismic regulations for new buildings and other structures - Part1 Provisions. 2003, Building Seismic Safety Council: USA. 
13. FEMA-P750, NEHRP recommended seismic provisions for new buildings and other structures. 2009 , Building Seismic Safety Council: USA, Washington, D.C.

14. TI809-07, Design of cold-formed loadbearing steel systems and masonry veneer / steel stud walls. 1998, US Army Corps of Engineers, Engineering and Construction Division: Washington, D.C.

15. FEMA-302, NEHRP recommended provisions for seismic regulations for new buildings and other structures, in FEMA 302. 1998, Building Seismic Safety Council.

16. UBC, Uniform building code. 1997, International Conference of Building Officials: California, USA.

17. IBC, International building code. 2006, International Code Council.

18. AS1170.4, Structural design actions, Part 4: Earthquake actions in Australia. 2007, Standards Australia.

19. AS/NZS4600, Cold-formed steel structures, AS/NZS 4600. 2005, Australian Building Codes Board.

20. Serrette, R.L. (1997), "Additional Shear Wall Values for Light Weight Steel Framing." Report No. LGSRG-1-97, Santa Clara University. Santa Clara, CA.

21. Kawai Y, Kanno R, Hanya K. (1997), "Cyclic Shear Resistance of Light-Gauge Steel Framed Walls", Portland, OR, USA: ASCE, p. 433-7.

22. Berman J.W., Celik O.C., Bruneau M., (2005), "Comparing Hysteretic Behavior of Light-Gauge Steel Plate Shear Walls and Braced Frames", Engineering Structures, 27:475-85.

23. ATC-24. (1992), "Guidelines for Cyclic Seismic Testing of Components of Steel Structures", USA: Applied Technology Council, National Center for Earthquake Engineering Research.

24. Schafer B.W., and Hiriyur B. (2002), "Analysis of Sheathed Cold-Formed Steel Wall Studs", Orlando, FL, United states: University of Missouri-Rolla, p. 501-13.

25. Fulop L.A. and Dubina D. (2004), "Performance of Wall-Stud Cold-Formed Shear Panels under Monotonic and Cyclic Loading - Part I: Experimental Research", Thin-Walled Structures, 42:321-38.

26. FEMA-450, NEHRP recommended provisions for seismic regulations for new buildings and other structures - Part 2 commentary. 2003, Building Seismic Safety Council: USA.

27. Uang, C.-M., Establishing $R$ (or $R w$ ) and Cd factors for building seismic provisions. Journal of Structural Engineering, 1991. 117(1): p. 19-28.

28. FEMA-356, Pre standard and commentary for the seismic rehabilitation of buildings. 2000, AMERICAN SOCIETY OF CIVIL ENGINEERS: USA, Virginia.

29. Uang, C.-M., Establishing $R$ (or $R w$ ) and Cd factors for building seismic provisions. Journal of Structural Engineering, 1991. 117(1): p. 19-28.

30. Park, R., Evaluation of ductility of structures and structural assemblages from laboratory testing. Bulletin of the New Zealand National Society for Earthquake Engineering, 1989. 22(3): p. 155-166.

31. Gad, E.F., et al., Earthquake ductility and overstrength in residential structures. Structural Engineering and Mechanics, 1999. 8(4): p. 361-382.

32. Maheri, M.R. and R. Akbari, Seismic behaviour factor, R, for steel X-braced and knee-braced RC buildings. Engineering Structures, 2003. 25(12): p. 1505-1513.

33. Kim, J. and H. Choi, Response modification factors of chevron-braced frames. Engineering Structures, 2005. 27(2): p. 285-300.

34. Newmark, N. and W. Hall, Earthquake spectra and design. 1982: Earthquake Engineering Research Inst. Berkeley, CA.

35. Serrette, R. and K. Ogunfunmi, Shear resistance of gypsum-sheathed light-gange steel stud walls. Journal of structural engineering New York, N.Y., 1996. 122(4): p. 383-389.

36. US Army Corps of Engineers, TI 809-07, Technical Instructions, Design of Cold-Formed Loadbearing Steel Systems and Masonry Veneer / Steel Stud Walls. 1998: Washington, DC 20314-1000.

37. LabVIEW, LabVIEW SignalExpress. 2007, National Instruments Corporation: Austin, Texas. 
38. E2126-07, A.-. Standard test methods for cyclic (reversed) load test for shear resistance of walls for buildings. 2007: USA. p. 13.

39. Gad, E.F., et al., Lateral performance of cold-formed steel-framed domestic structures. Engineering Structures, 1999. 21(1): p. 83-95.

Received 02.03.2013

Revised 10.06.2013 